București, locuri reinventate / Sectorul 3

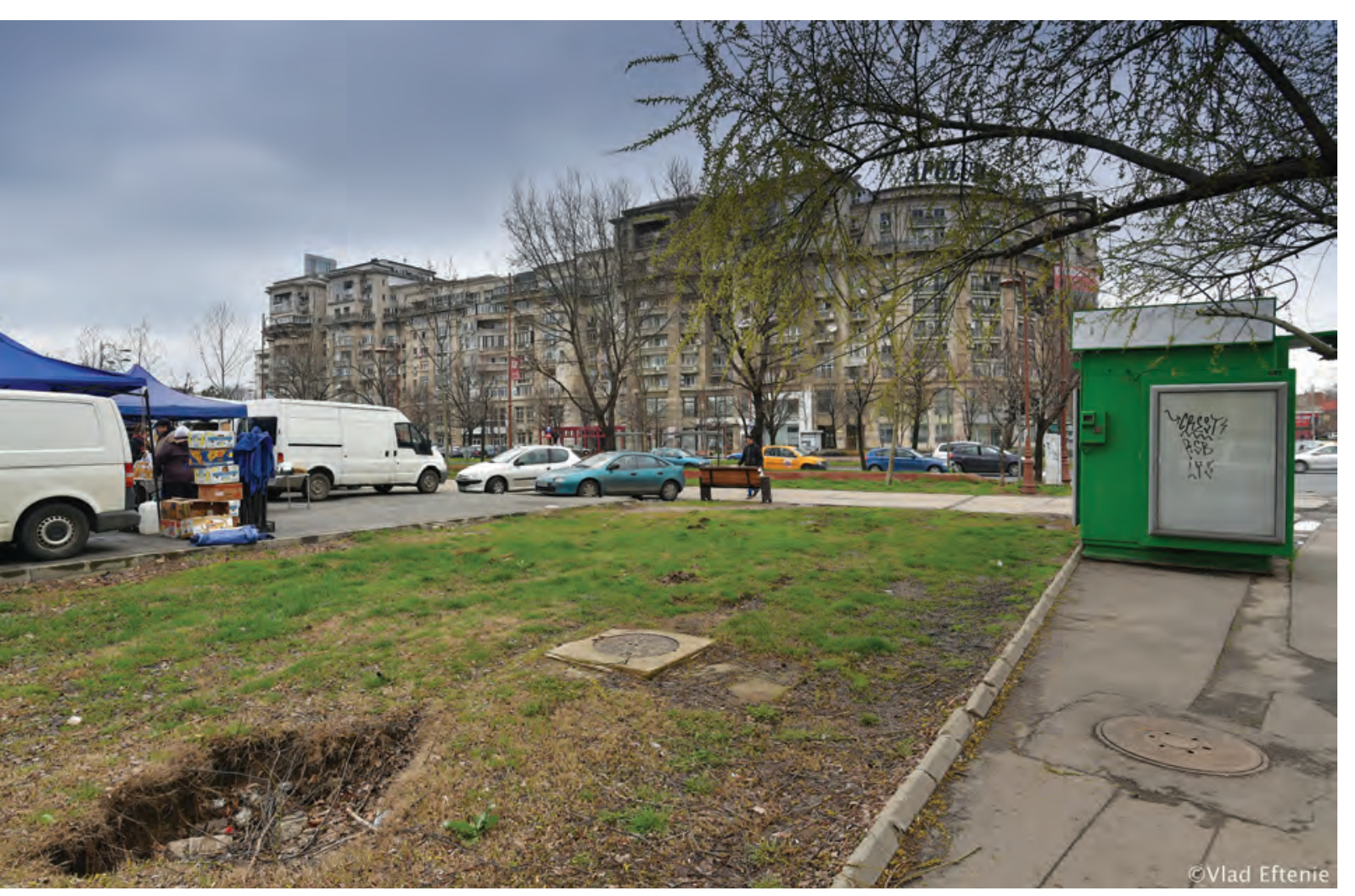

SITE
Unirii Bd-
Nerva Traian Str.

SITE
Unirii Bd-
Nerva Traian Str.

SITE
Unirii Bd-
Nerva Traian Str.

Bd. Unirii /

Str. Nerva Traian

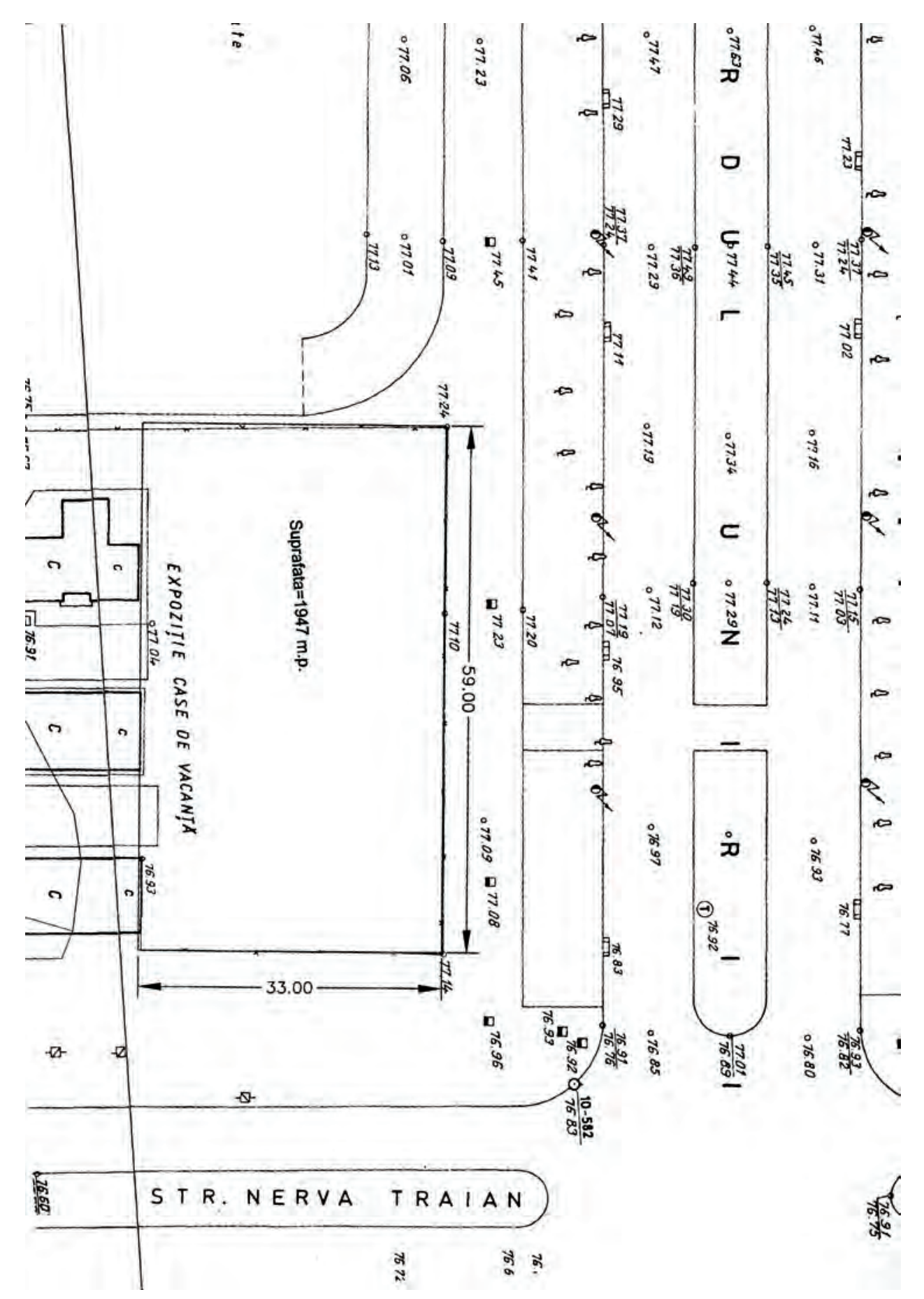




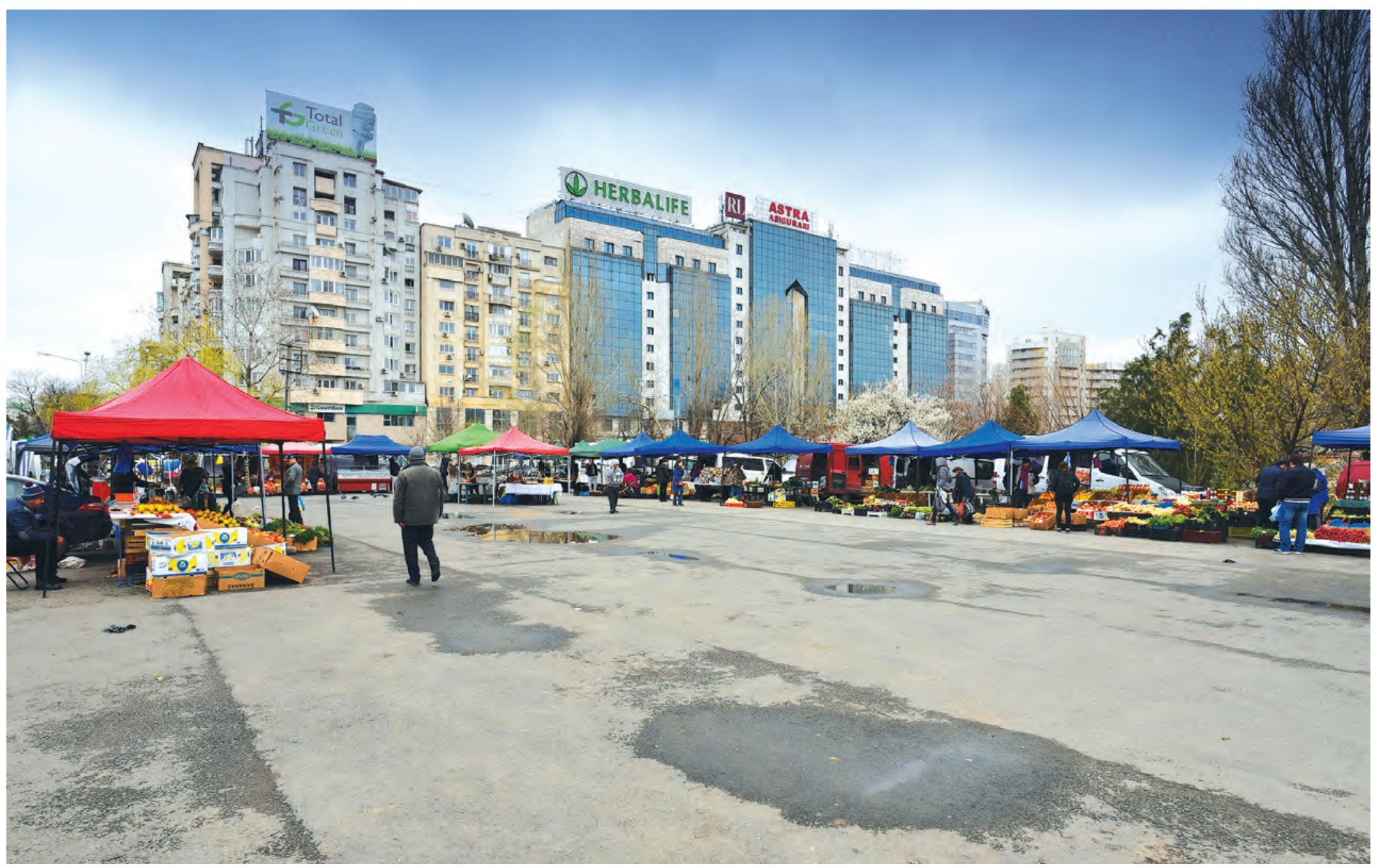

echipa de lucru /

work team:

Nemes KAROLY

arhitect / architect

Bogdan HOJBOTĂ

artist

Ne aflăm pe locul uneia dintre intersecțiile de mare forță ale orașului, la capătul unui spațiu dominat și azi de indecizie urbanistică - deși acest loc are o istorie recentă marcată de cel puțin patru intenții majore (Concursul București 2000, Centrul Esplanada, Centrul Culturii Scrise, Aria de Justiție). Aici se „încheie”, practic, geografia Centrului Istoric și „începe” Sudul Orașului, dominat de prezența Dâmboviței, a Lacului Văcărești, de o topografie fundamental-rurală anulată de urbanismul proletariatului. Un spațiu sensibil, deschis, destinat publicului, poate mult mai mare decât cel sugerat de noi, ar fi „,vectorul” de la care ar trebui repornită redefinirea acestui loc.

We are at the site of one of the city's major intersections, at the end of some space dominated even today by an urbanistic indecision - although this place has a recent history marked by at least four major intentions (Bucharest 2000 Contest, Esplanade Center, Center for Written Culture, Area of Justice). Here, basically, „ends” the geography of the Historic Center and „begins” the Southern City, marked by the presence of Dambovita, by Văcăresti Lake, by a fundamental-rural topography canceled by the urbanism of the proletariat. A sensitive, open space for the public, maybe much larger than what we dare to suggest, would be the „vector” from which the redefinition of this place should be restarted. 


\section{Bogdan HOJBOTĂ}

Efemeridă, apă, zbor...
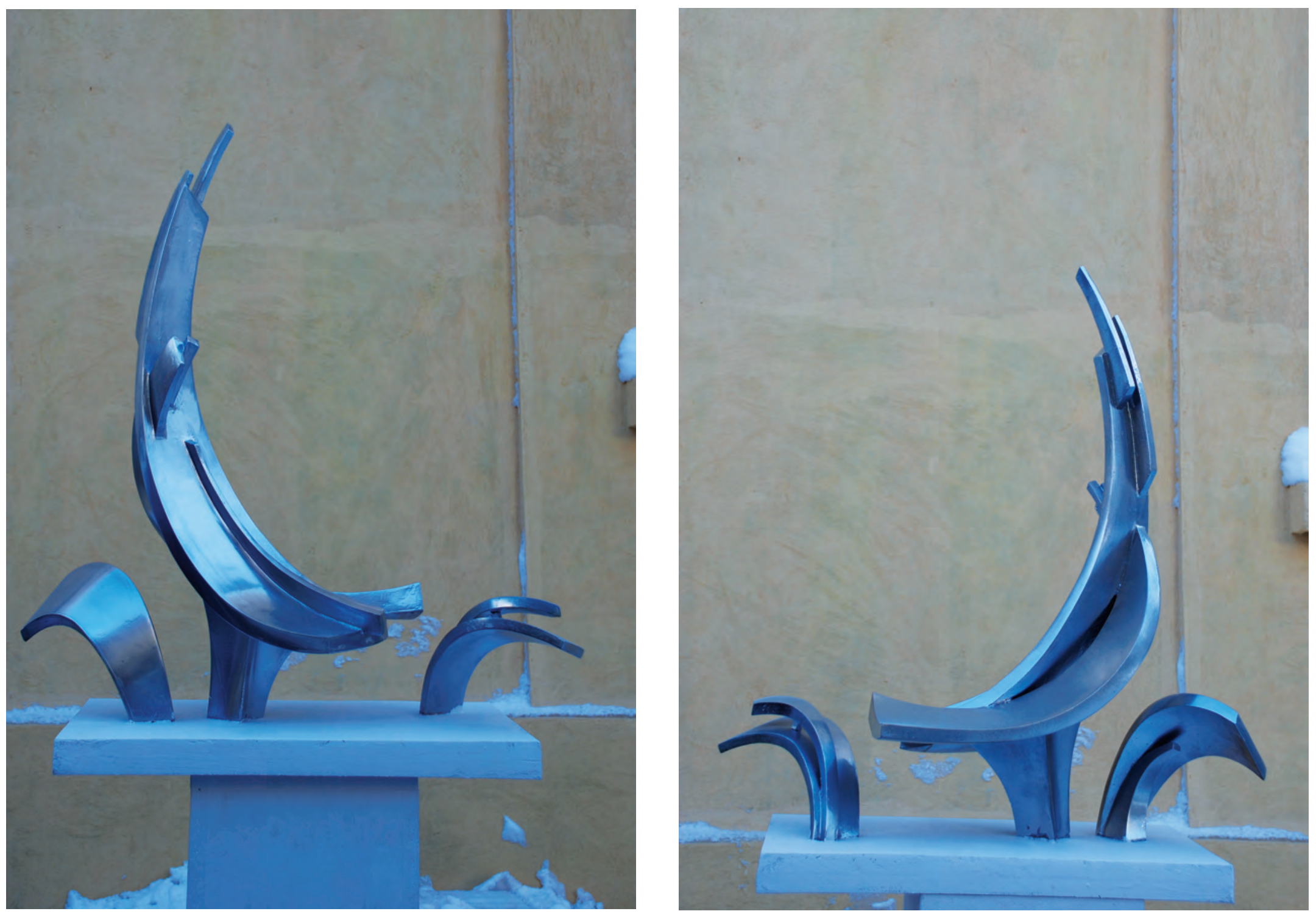

Întrunind trei din cele 4 elemente primordiale, și pentru că putem accepta că la întâlnire este prezent și cel de-al patrulea (metalul, ca produs al focului), creația artistică este împlinită. Apa, prezentă ca element originar, reflectând și dând dimensiune profundă lumii naturale, dar și artificiale, amplifică și subliniază eleganța formelor lansate spre cer într-o întoarcere în înalt. Datorită ei, întregul capătă, grație devenirii permanente a lumii, calitățile artei cinetice.

Metalul (inox) din care este realizată piesa centrală este valorificat nu doar prin eleganța și cursivitatea formelor armonios lansate, ci și prin forța conținută degajând ideea de zbor ușor, curajos și jucăuș. Efemerida, ea însăși semn și chip al trecătorului, este, prin asumarea schimbării permanente a lumii, reflectată simultan de metal și de apă, un simbol al mișcării, al schimbării, al zborului, ca si al înălțării. Formele abstracte, prin eleganța firesc necesară a sinuozităților și prin dependența permanentă de lumină, sugerează visul spre înalt, zborul ca stare și dorință lăuntrică. Realizarea armoniei întregului se datorează pe de o parte sculpturii în sine, pe de alta sugerării formelor centrale prin plasarea repetitivă în spațiu a unor piese de piatră ce se oferă publicului atât ca loc de odihnă, cât și ca o completare ideală a ansamblului din punct de vedere estetic. Admițând repetiția ca subliniere, caracterul cinetic, dinamic, datorat formelor și materialului piesei centrale valorifică amplificând datele naturale ale amplasamentului prin relația luminii cu elementele primordiale - apa, aerul, focul și pământul.

Întregul complex, sculptura plasată în centrul optic și nu geometric al bazinului, băncile subliniind formele centrale, dovedesc împreună grija pentru detaliu, întrunind calitățile estetice necesare și suficiente unui asemenea amplasament urban. 


\section{Bucharest, reinvented places / 3rd District}

\section{Ephemeris, water, flight}

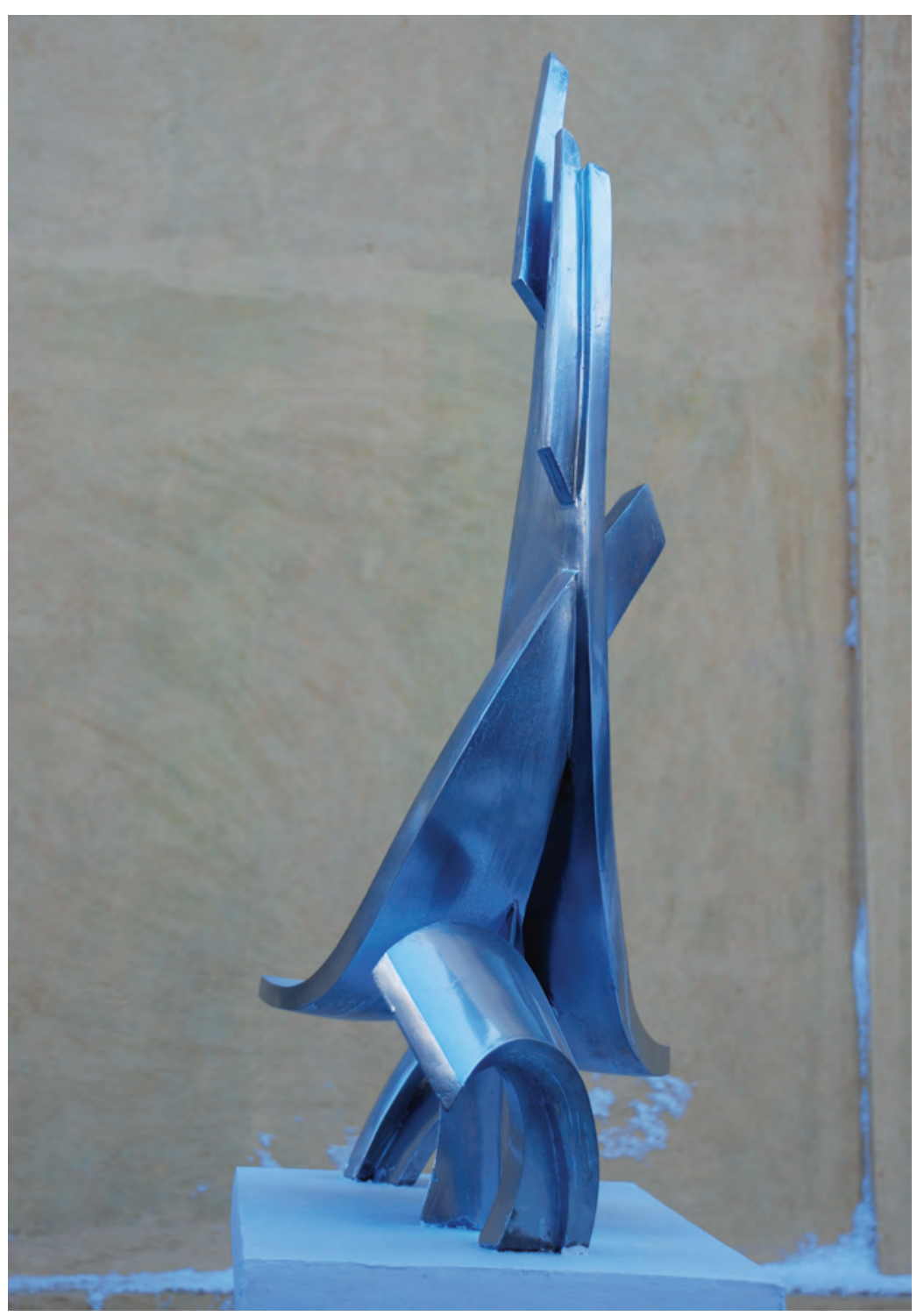

Efemerida, sculptură de Bogdan Hojbotă

Ephemeris, sculpture by Bogdan Hojbotă

Gathering three of the four primordial elements, and because we can accept that the fourth (metal as a product of fire) is also present at this meeting, the artistic creation is fulfilled. The water, present as a native element, reflecting and giving a deep dimension to the natural and artificial world, amplifies and emphasizes the elegance of the forms launched to the sky in a high return. Thanks to it, the whole receives, thanks to the permanent becoming of the world, the qualities of kinetic art. The metal (stainless steel) of which the central piece is made is redeemed not only by the elegance and cursivity of the harmonious forms launched, but also by the force contained by the idea of a light, courageous and playful flight. The Ephemeris, sign and face of the evanescence in itself, assuming the constant change of the world, simultaneously reflected by metal and water, is a symbol of movement, change, flight, and ascension. The abstract forms, by the natural necessity of sinuosity and by the constant dependence of light, suggest the dream to the high, the flight as the state and the inner desire. The realization of the harmony of the whole is due on the one hand to the sculpture itself, on the other of the suggestion of the central forms by the repetitive placement of some pieces of stone that are offered to the public both as a resting place and as an ideal complement of the ensemble from the aesthetic point of view. Admitting the repetition as an emphasis, the kinetic, dynamic character due to the forms and material of the central piece capitalizes on amplifying the natural data of the site through the relationship of light with the primordial elements - water, air, fire and earth. The whole complex, the sculpture placed in the optic and not geometric center of the basin, the banks emphasizing the central forms, together show the care for detail, meeting the aesthetic qualities necessary and sufficient for such an urban location. 
București, locuri reinventate / Sectorul 3

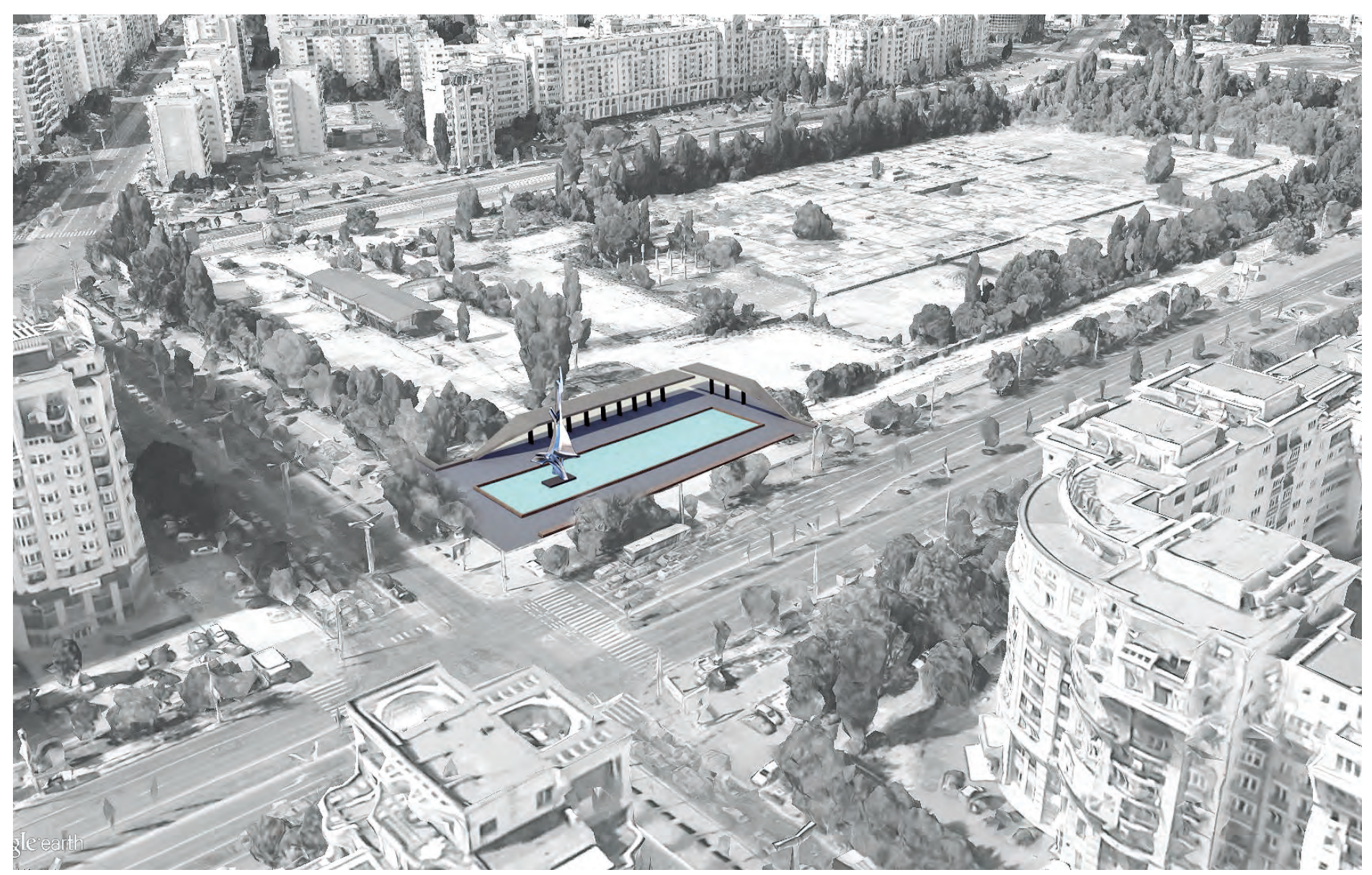

vedere de sus a zonei și propunere (randare); pagina alăturată - propuneri, perspective (randare), autor Dragoș Perju top view of the area and proposal (rendering); next page - proposals, perspectives (rendering), author Dragoș Perju

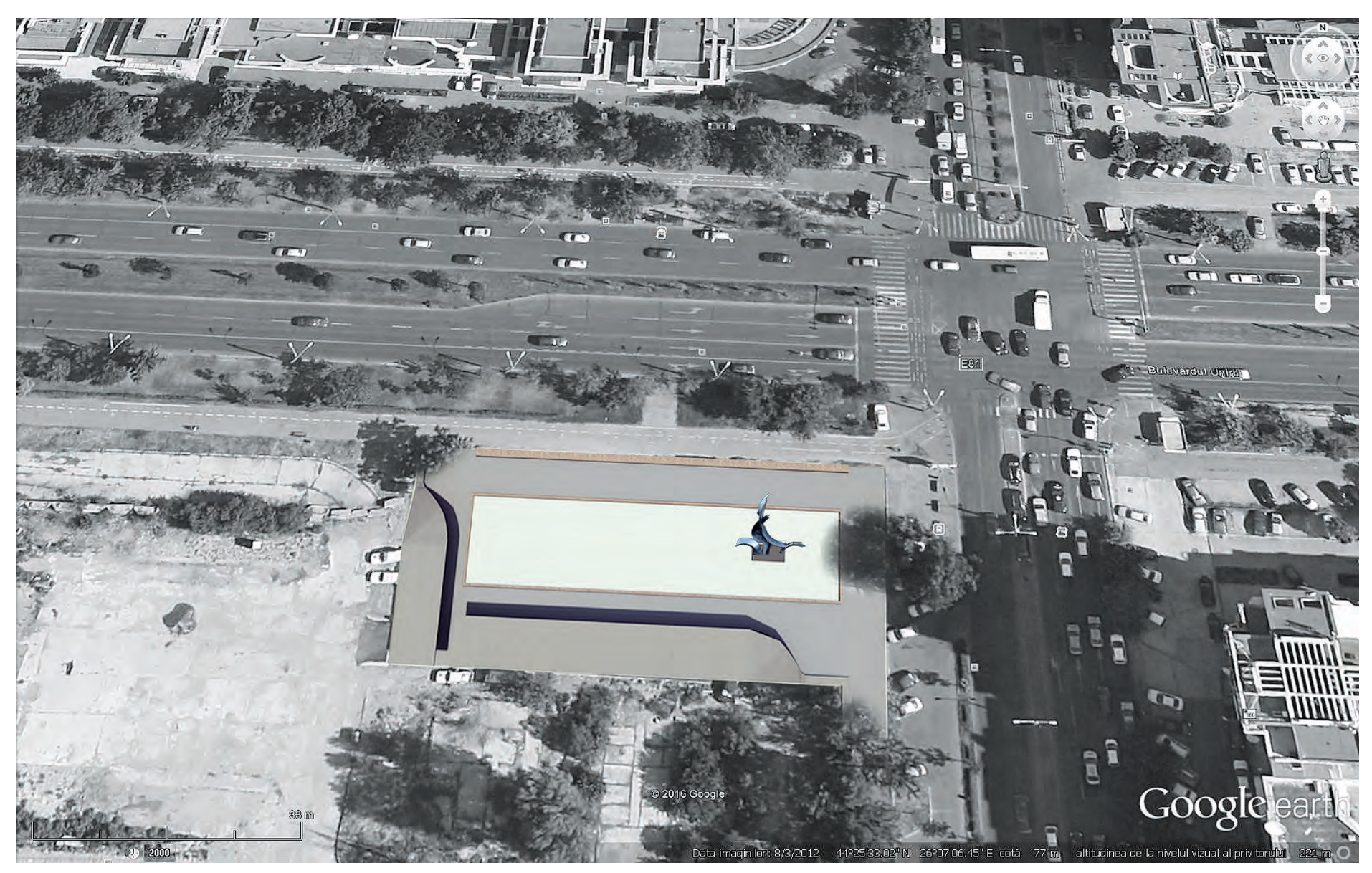



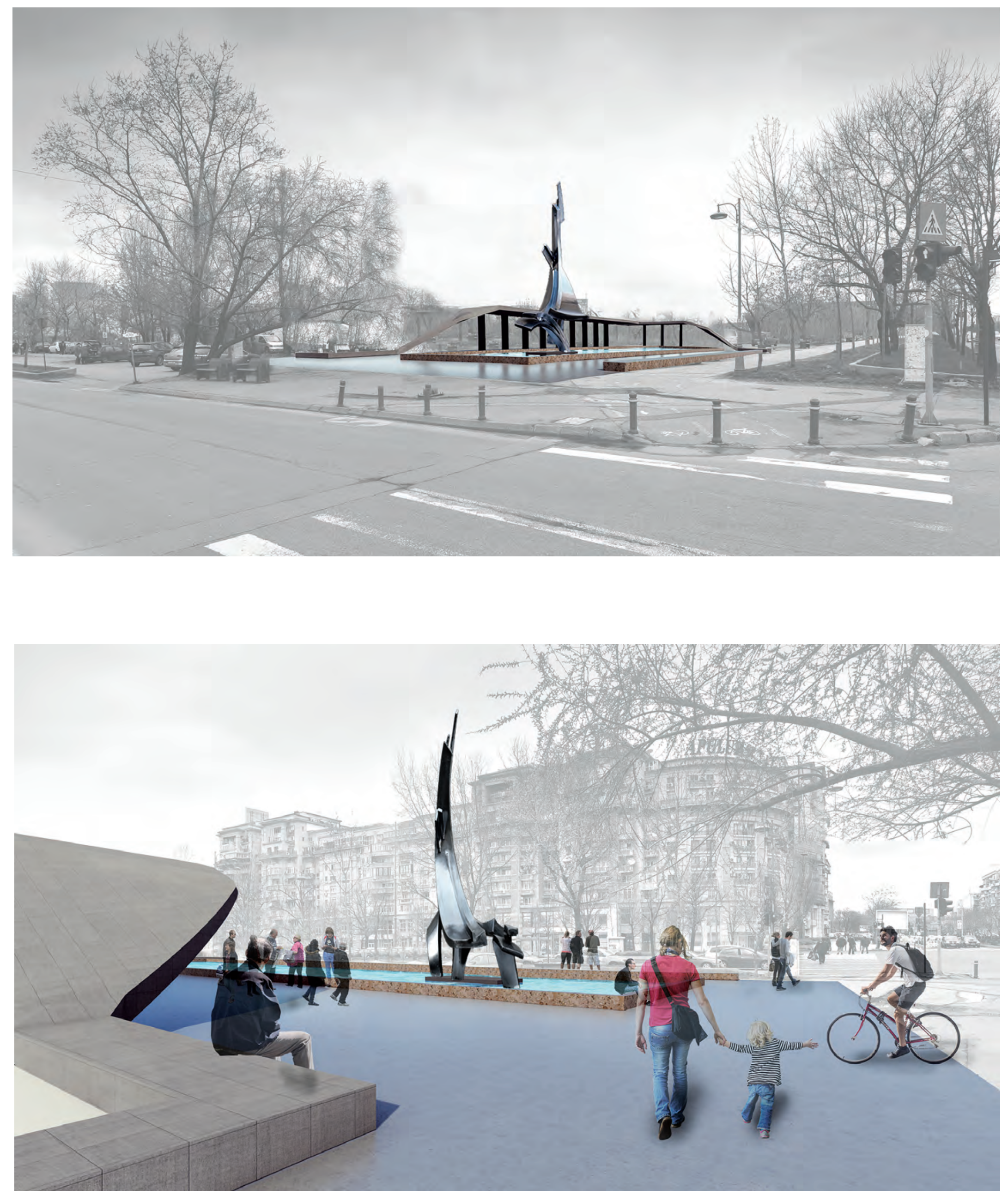
București, locuri reinventate / Sectorul 3

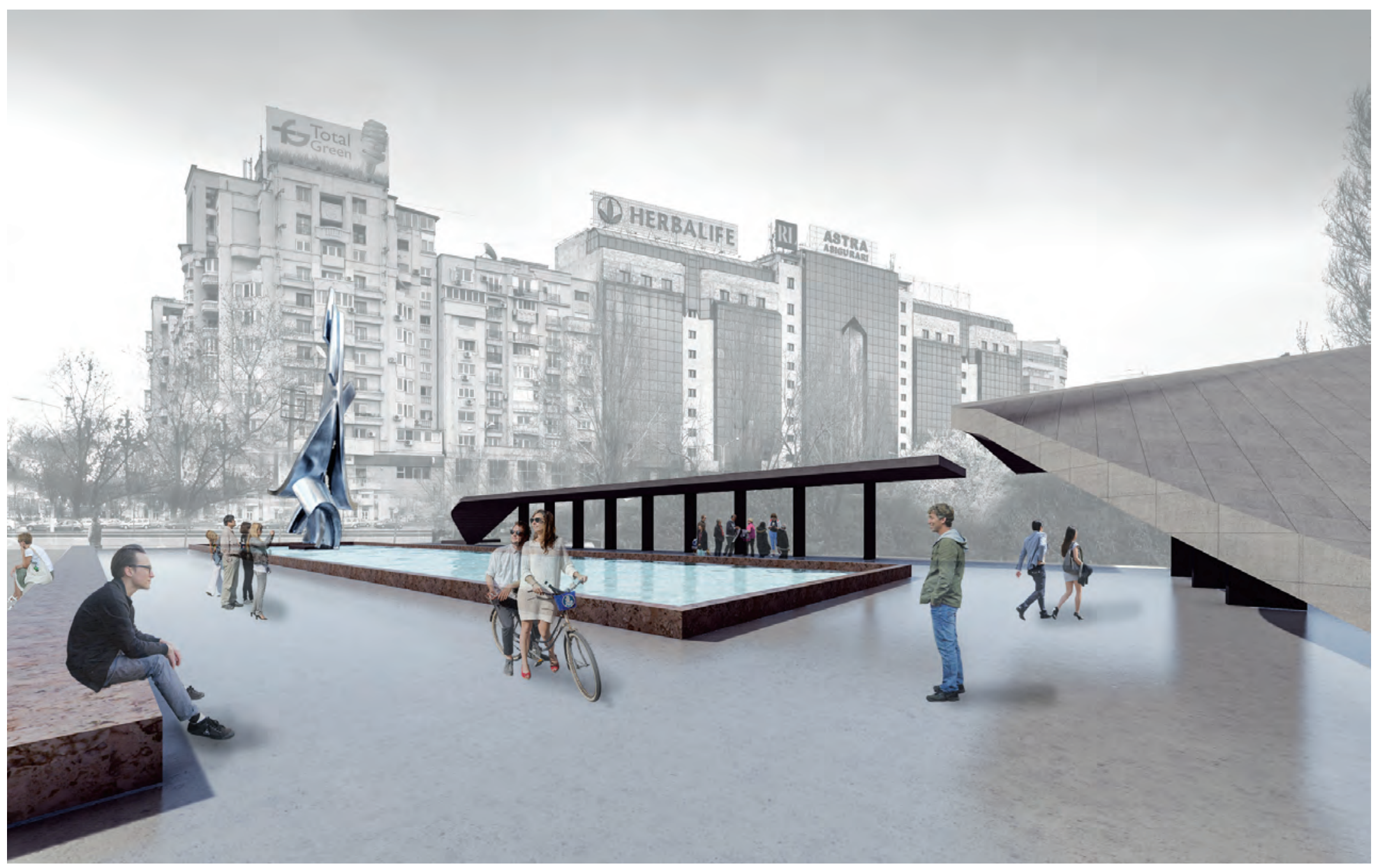

propunere de amenajare (randare), autor Dragoș Perju

design of the area, proposition (rendering), author Dragoș Perju 


\section{Bogdan HOJBOTĂ \& Nemes KAROLY Un spațiu de personalizat}

Un loc aflat la intersecția a două artere de importanță diferită, atât ca istorie, cât și ca amploare. Una, veche, de orientare nord-sud, într-un fel paralel și complementar Căii Moșilor, ce lega mahalele dinspre Bariera Vergului (un fel de centură de est a târgului-capitală din secolul XIX), iar cealaltă un bulevard post-haussmanian, creat dintr-un imbold ideologic și nu neapărat urbanistic, dar cu aportul nemijlocit al celui din urmă, Bdul ex-Victoriei Socialismului, actualmente „al Unirii” cu construcții post-moderne nu foarte reușite arhitectural (și nici constructiv), dar cu un spațiu public-pietonal amplu, poate prea mare, dar după ultimele intervenții la nivelul trotuarului, cu o distribuție a spațiului verde vs mineral mult mai bine realizat. Acest loc, unde azi se „ține” piața de legume-fructe a zonei, cartierului, sub umbrele așezate pe asfalt, este delimitat pe laturile nord și est de construcțiile din perioada socialistă, blocuri de locuit cu comerț și servicii la parter, dezvoltate pe I0-II niveluri, iar pe laturile opuse avem o relicvă „subterană” a aceleiași epoci care a măturat mărturiile locului, istoria veacurilor trecute. Pe de o parte avem un zid înalt, monoton și aproape brutal prin lipsa vis-a-vis-ului, iar pe partea celalaltă un vid plan, un gol urban, un spațiu „neurbanizat” momentan (ce durează de aproape trei decenii), cu nenumărate posibilități de dezvoltare - undeva în următoarele decenii. Am dorit să personalizăm acest spațiu „,neurbanizat”- colț de stradă printr-o intervenție pe mai multe paliere: I) spațiul urban-arhitectural să-I configurăm printr-o retragere de la cele două artere, creând o piațetă urbană, un vid al colțului;

2) acest „vid”, piațeta, s-o dublăm-amplificăm cu un bazin de apă, o oglindă urbană - omagiu adus pavilionului de la Barcelona al lui Mies;

3) pe acest piedestal orizontal, infinit prin oglindire, am amplasat obiectul artistic - instalația artistică in situ, un semnal, o viță de vie sau o moară de apă, evocând urme ale trecutului zonei - din oțel inox sau zincat, ca un contrapunct - formal și material - al peretelui urban „de peste drum”;

4) piațeta am delimitat-o spre laturile deschise către fundațiile construcției socialiste cu o copertină ce urmează în plan forma pieței și a bazinului de apă, care în vederea-secțiune pornește de la nivelul trotuarelor celor două artere și se înalță ca o panglică deasupra laturilor piațetei - trecând prin diferite ipostaze de trotuar, banchetă, pantă sau copertină;

5) această „ramă”, panglica construită, tridimensională, are menirea funcțională de a adăposti - trecători, târgoveți, produse-fructe și legume în timpul zilei, iar după apus, prin iluminatul realizat, va fi scenă de întâlnire pentru locatarii zonei-cartierului în ideea citatului „Mai mult decât o Capitală, Bucureștiul e un loc de întâlnire" (Paul Morand);

6) totodată, această construcție cu obiect artistic va constitui poarta de intrare în viitoarea dezvoltare urbană dinspre Dâmbovița. Materiale propuse: piatră-granit, apă, oțel-inox sau chiar oțel zincat, tablă de oțel ruginit, lumini.

\section{A space to personalize}

A place at the intersection of two arteries of different importance, both in history and in scale. One, old, north-south orientation, in a parallel and complementary way to the Horses of the Moors, linking the slums from the Vergu Barrier (a kind of eastern belt of the nineteenth-century capital), and, on the other hand, a post-Haussman boulevard, created from an ideological, not necessarily urbanistic, impulse but with the direct contribution of the latter, The Boulevard of the Ex-Victory of Socialism, currently „Union” with post-modern construction not very successful architectural (but neither constructive), „gifted” with an ample public space-pedestrian area, perhaps too large, but after the last pavement interventions, with a much better distribution of green space vs. mineral space. This place, where today is the „fruit-market" of the area, district, under the asphalt shadow is delimited on the north and east sides by the socialist construction, residential blocks with commerce and ground floor services, developed on I0-II levels, and, on the opposite sides, we have an ,underground" relic of the same era that swept the testimonies of the place, the history of past ages. We wanted to personalize this „un-urbanized” space - the corner, through an intervention on many levels:

I) to set up the urban-architectural space by a retreat from the two arteries, creating an urban marketplace, a vacuum of the corner;

2) this „vacuum”, the square, we double-amplify it with a water basin, an urban mirror - paying tribute to Mies Barcelona's pavilion;

3) on this horizontal pedestal, infinite by mirroring, we placed the artistic object - an in situ artistic installation, a signal, a vine or a water mill, evoking traces of the area's past - made of stainless steel or zinc, as a counterpoint - of the urban wall "from the other side"; 4) we delimited the square to the open sides to the foundations of socialist construction with a cover that follows the shape of the market and the water basin, which in section view starts from the sidewalks of the two arteries, and it rises like a ribbon above the sides of the square, passing through different sidewalks, banquet, sunshade or cover;

5) this ,frame”, the built, three-dimensional ribbon, has the functional function to host - passers-by, fruit, and vegetables during the day, and after sunset, through the illumination made, there will be a meeting scene for the residents of the neighborhood, as the writer said: „More than a Capital, Bucharest is a meeting place”.(Paul Morand);

6. moreover, this construction with artistic object will be the gateway to the future urban development from Dâmbovita; Proposed materials: stone-granite, water, stainless steel or even galvanized steel, rusty steel sheet, lights. 